University of Nebraska - Lincoln

DigitalCommons@University of Nebraska - Lincoln

Faculty Publications from the Harold W. Manter Laboratory of Parasitology

9-1957

\title{
Distribution and Specificity of Helminths in Microtine Rodents: Evolutionary Implications
}

Robert L. Rausch

United States Arctic Health Research Center, rausch@u.washington.edu

Follow this and additional works at: https://digitalcommons.unl.edu/parasitologyfacpubs

Part of the Parasitology Commons

Rausch, Robert L., "Distribution and Specificity of Helminths in Microtine Rodents: Evolutionary Implications" (1957). Faculty Publications from the Harold W. Manter Laboratory of Parasitology. 522. https://digitalcommons.unl.edu/parasitologyfacpubs/522

This Article is brought to you for free and open access by the Parasitology, Harold W. Manter Laboratory of at DigitalCommons@University of Nebraska - Lincoln. It has been accepted for inclusion in Faculty Publications from the Harold W. Manter Laboratory of Parasitology by an authorized administrator of DigitalCommons@University of Nebraska - Lincoln. 


\title{
DISTRIBUTION AND SPECIFICITY OF HELMINTHS IN MICROTINE RODENTS : EVOLUTIONARY IMPLICATIONS
}

\author{
ROBERT RAUSCH \\ Arctic Health Research Center, U. S. Public Health Service, Anchorage
}

Received February 16, 1957

Among those genera of microtine rodents having holarctic distribution, the parasitic helminths of North American representatives of Dicrostonyx, Lemmus, Clethrionomys, and Microtus are relatively well known. These helminths demonstrate a highly developed phylogenetic specificity, being restricted essentially to the Microtinae, but few show any evidence. of host-specificity at the generic level. Both nematodes and cestodes are prevalent endoparasites of these rodents in boreal North America. For the purposes of the present work, emphasis is placed upon the cestodes, most of which are members of the subfamily Anoplocephalinae. Some of the latter are unusually interesting in that they occur in a variety of host-species over extensive geographic ranges. With the exception of Paranoplocephala omphalodes (Hermann, 1783), it has not been determined whether these cestodes are holarctic. It is evident, however, that some described from microtine rodents in Eurasia correspond morphologically to species in North America.

It appears in Alaska that significant relationships between the distribution of certain cestodes and the distribution of their hosts may be recognized. Any attempt to evaluate these apparent relationships is contingent upon determining whether or not these cestodes are holarctic. The study of this problem has now been undertaken in light of work published recently by Eurasian helminthologists and the acquisition of additional comparative material. This paper contains a review of the taxonomic status of anoplocephaline cestodes from microtine rodents and a discussion of some of the evolutionary and zoogeographic implications of distribution and host-occurrence of these and other helminths.

I. The genus Andrya. Five species of Andrya parasitic in microtine rodents may be considered valid at the present time.

1. Andrya macrocephala Douthitt, 1915, is the most common cestode observed in species of Microtus in North America. Its unusually wide range of normal morphological variation (Rausch and Schiller, 1949a; Rausch, 1952) has led to the description of some of its variants as distinct species. A. macrocephala has been well characterized from North American material. Two species closely resembling A. macrocephala have been described in Eurasia; however, their validity is questionable. One of these, $A$. bialowizensis Sołtys, 1949, has been reported only from Poland. A. caucasica Kirshenblat, 1938, was described from Transcaucasia.

It was suggested by Rausch and Schiller (1949a) that $A$. caucasica might be conspecific with $A$. macrocephala. This possibility was not considered by Spasskii (1951), in his monograph of anoplocephalid cestodes. Later, Spasskii, Romanova, and Naidenova (1951) made a survey of the helminth parasites of muskrats (an introduced species) in Russia, and from this host collected specimens of Andrya in the Kurgansk and Archangel'sk Oblasti. They also had cestodes of this genus from voles in Pribaikal'. These workers noted the lack of significant morphological differences between these specimens and the description of $A$. macrocephala. It was also observed that the cestodes from the voles of Pribaikal' did not differ in any essential way from $A$. caucasica and $A$. 
bialowizensis. They concluded that the latter two species are either conspecific with $A$. macrocephala or that a distinct palearctic species exists which is morphologically indistinguishable from the latter. In this event, it was believed that $A$. $b i$ alowizensis would be a synonym of $A$. caucasica. However, since other criteria are lacking, the taxonomy of these cestodes can only be based upon their morphology. More recently, Żarnowski (1955) studied specimens of Andrya from voles from the environs of Puławy, Poland. He observed the usual wide range of morphological variation in this material, and concluded that $A$. caucasica is conspecific with A. macrocephala. Although Żarnowski did not consider the status of A. bialowizensis, it is morphologically. identical with $A$. macrocephala and cannot justifiably be regarded as distinct. Consequently, $A$. caucasica Kirshenblat, 1938, and A. bialowizensis Sołtys, 1949, may be added to the list of synonyms of A. macrocephala.

2. Andrya primordialis Douthitt, 1915, was described from a squirrel, Tamiasciurus, in North America. At the same time, A. communis Douthitt, 1915, was described from a red-backed vole, but it was regarded as a synonym of the former by Baer (1927). According to Douthitt (1915), A. primordialis differs from $A$. macrocephala in having a prostate gland and unilateral genital pores. Satisfactory material for comparative study has not been available, and the status of this cestode remains indefinite (Rausch, 1952; Schad, 1954).

3. Andrya montana Kirshenblat, 1941, is known from voles from Georgia and Armenia (see Spasskii, 1951, p. 397). From Spasskii's description, it is apparent that this cestode resembles $A$. primordialis in having a prostate gland and unilateral genital pores.

4. Andrya arctica Rausch, 1952, is widely distributed in arctic North America, where it has been recorded from Dicrostonyx, Lemmus, Clethrionomys rutilus, and species of Microtus. A poorly preserved cestode from Lemmus lemmus, collected at Enontekis, Finland, has been tentatively referred to this species (Rausch, 1952). This cestode may be holarctic in distribution.

5. Andrya bairdi Schad, 1954, is a unique form, known only from Microtus chrotorrhinus from the type locality (Quebec, Canada). It is characterized by unilateral genital pores and the absence of a prostate gland.

II. The genus Paranoplocephala. Six species of Paranoplocephala occurring in microtine rodents are recognized here:

1 and 2. Paranoplocephala omphalodes (Hermann, 1783) has been reported frequently from western Europe. Farther east in Poland, it was collected by Pojmańska (1956) from voles near Poznań, and by Sołtys (1949) from voles in the Białowieza Forest. Spasskii (1951) listed its occurrence in the following localities in Russia: Voronezh Oblast', Volga delta, Armenia, Georgia, West Siberia, and Chita Oblast'. In North America, it is known only from Alaska.

$P$. omphalodes as defined by Baer (1927) is a well characterized species. Its status is confused, however, by the fact that $P$. blanchardi (Moniez, 1891) is currently regarded by most workers as being synonymous with it. P. blanchardi was considered distinct by Baer (1927), in his monograph of the Anoplocephalidae. He later (1932) concluded that a single, variable species exists which, according to his definition, would be dimorphic. In support of his conclusion, he stated (p. 5), "En effet, la seule différence entre ces deux Cestodes réside dan le fait que chez $P$. omphalodes, les pores génitaux alternent irrégulièrement, tandis qu'ils sont unilatéraux chez $P$. blanchardi. D'autre part, $P$. omphalodes est beaucoup plus grand que $P$. blanchardi. Leurs anatomies sont identiques, tous deux ont 50 testicules par segment, une poche du cirre longue de $0,2 \mathrm{~mm}$ à $0,4 \mathrm{~mm}$ et des oeufs de $40 \mu$ à $60 \mu$ de diamètre. Or nous trouvons dans notre matériel un Ver long de $50 \mathrm{~mm}$ et large de $2 \mathrm{~mm}$ ( $P$. 
blanchardi), mais avec des pores génitaux alternants. D'autre part, nous trouvons des Vers longs de $80 \mathrm{~mm}$ et larges de 5 mm ( $P$. omphalodes), mais avec les pores génitaux unilatéraux. Il n'existe donc pas de caractère spécifique valable permettant de séparer ces deux espèces l'une de l'autre. $P$. omphalodes ayant priorité sur $P$. blanchardi, ce dernier nom doit tomber en synonymie avec le premier." Cameron and Parnell (1933, p. 148) reached the same conclusion regarding the two species: "We found several specimens of this tapeworm in the small intestine of a vole from Caithness. In one, the genital pores were completely unilateral; in another they were irregularly alternating, about half a dozen to a dozen opening on one side to be succeeded by a similar number opening on the other. We have seen a similar phenomenon in specimens of Hymenolepis diminuta from the rat, and we are in agreement with Baer that $P$. blanchardi cannot be differentiated from $P$. omphalodes on this point and that the former name is a synonym of the latter."

Joyeux and Baer (1936, p. 44) stated that $P$. omphalodes may have either a length of 20 to $40 \mathrm{~mm}$ and unilateral genital pores, or a length of 100 to $215 \mathrm{~mm}$ with irregularly alternating pores. This view was reiterated by Baer (1949, p. 43).

Spasskii (1951, p. 307) reviewed this problem, after having studied cestodes from the Novosibirsk Oblast' which corresponded in some details with the description of $P$. blanchardi. He regarded the published accounts of the status of $P$. blanchardi as being "contradictory and incomplete" and gave a detailed description of the Novosibirsk specimens.

Cestodes from Alaska identified as $P$. omphalodes correspond to Baer's (1927) characterization in their relatively large size, in having irregularly alternating genital pores, in size of egg, number and distribution of testes, and size of the cirrus sac. They also were morphologically identical with specimens in the writer's possession from Microtus from
Belgium. In a series of more than 50 cestodes with gravid segments, most of which were collected from Microtus on St. Matthew Island, Alaska, nothing approaching the smaller form with unilateral genital pores was seen. It is difficult to believe that the range of normal variation in $P$. omphalodes would be so great as to account for the form designated as $P$. blanchardi. Arrangement of the genital pores (whether unilateral or irregularly alternating) provides an important differential character in the anoplocephaline cestodes; other than the findings of the European workers regarding $P$. omphalodes-blanchardi, there is no evidence that this character is subject to variation within a given species. The relatively wide range of morphological variation in $A$. macrocephala, for example, was never observed to include any deviation from the irregularly alternate arrangement of the genital pores (Rausch and Schiller, 1949a). The study of a large series of specimens from Europe should show a gradation in size if a single species were involved, rather than two non-intergrading size-groups. Apparently specimens of the larger size have never been observed to possess unilateral pores. It appears that $P$. blanchardi is a distinct species.

No cestodes conforming to the description of $P$. blanchardi have been found in North America. It may be that this form is the Eurasian counterpart of the nearctic P. variabilis (Douthitt, 1915). The latter and $P$. neofibrinus Rausch, 1952, resemble $P$. blanchardi, but in number of testes, size of cirrus sac, and size of egg are dissimilar. Further study of Eurasian material is needed.

3. Paranoplocephala infrequens (Douthitt, 1915) is a very common parasite of Microtus spp. in North America. It is distributed over much of the continent and is also morphologically variable (Rausch, 1952).

A cestode designated as $P$. brevis Kirshenblat, 1938, is recognized in Eurasia. Since first collected from voles in Georgia (Kirshenblat, 1938), it has been 
recorded from several localities, and appears to be a relatively common cestode. Spasskii (1951) recorded P. brevis from Armenia and the Barbinskoi Steppe (Novosibirsk Oblast'). Żarnowski (1955) collected it in the environs of Pulawy, and Pojmańska (1956) found it in voles from the vicinity of Poznań. Heretofore, $P$. brevis has not been reported west of Poland. It was suggested by Rausch and Schiller (1949b) that $P$. brevis may be conspecific with $P$. infrequens, since there appear to be no morphological differences. Spasskii (1951) stated (p. 312) in reference to $P$. brevis: "In its anatomomorphology and ecology (habitat in the large intestine of the vole) is an indication this species is identical with $P$. troeschi Rausch, 1946, described from $\mathrm{a}$. vole in North America." P. troeschi is a synonym of $P$. infrequens (Rausch and Schiller, 1949b). Morphological variation in $P$. brevis was observed by both Spasskii (1951), who published descriptions of specimens from Siberia and from the Transcaucasus, and by Żarnowski (1955). The writer has from Belgian voles specimens which are clearly referable to $P$. infrequens and indistinguishable from $P$. brevis. Since these cestodes are obviously identical, $P$. brevis becomes a synonym of $P$. infrequens.

4. Paranoplocephala variabilis (Douthitt, 1915) is distributed over much of North America, including Alaska, but is unknown from Eurasia. It is of interest, however, that the cestodes described by Spasskii (1951, p. 308) from the Novosibirsk Oblast' resemble $P$. variabilis in some of the more important diagnostic characters. $P$. variabilis is most often found in Microtus spp.

5. Paranoplocephala lemmi Rausch, 1952 , is known only from boreal North America, where it occurs in Lemmus. This species, both morphologically and in its habitat requirement (cecum of the host), is similar to $P$. infrequens. $P$. lemmi may eventually be found to represent an extreme variant of $P$. infrequens.
6. Paranoplocephala neofibrinus Rausch, 1952, has been reported but once, from Neofiber in Florida. It certainly is not a part of the boreal fauna, and may be restricted to the one species of rodent. Additional work is needed to determine this.

\section{Discussion}

The present work is concerned with the helminths occurring in microtine rodents of the genera Dicrostonyx, Lemmus, Clethrionomys, and Microtus. These mammals are closely related phylogenetically, and their digestive tracts have become similarly adapted to a diet of relatively coarse, fibrous vegetation. They appear to fulfill more or less uniformly the habitat requirements of several species of helminths, although there are a few which demonstrate a definite host-specificity.

Dicrostonyx and Lemmus are relatively quite restricted in their distribution, and rodents representing the four genera coexist only in high-boreal regions. Also, in these animals several species of helminths are present only at high latitudes. Of the latter, a few range widely over the North American continent but most of these are holarctic species with apparently limited distribution in North America. The relationships of the helminths in microtine rodents as observed in Alaska are summarized in table 1. These are discussed below only in reference to genus of the host, since, with the exception of Microtus, each genus is represented in Alaska by only one species, and besides, we cannot yet define any differences existing at the species level.

Since Dicrostonyx is not always isolated ecologically from Lemmus and $M i$ crotus, it would seem that frequent exposure to infection by a variety of helminths would be unavoidable. It may be seen from the table that Dicrostonyx has few helminths in common with the other genera, Andrya arctica and Hymenolepis horrida being the only cestodes showing little development of host-specificity. Paranoplocephala variabilis was reported 
TABLE 1. Occurrence of the more common parasitic helminths in 4 genera of microtine rodents in Alaska

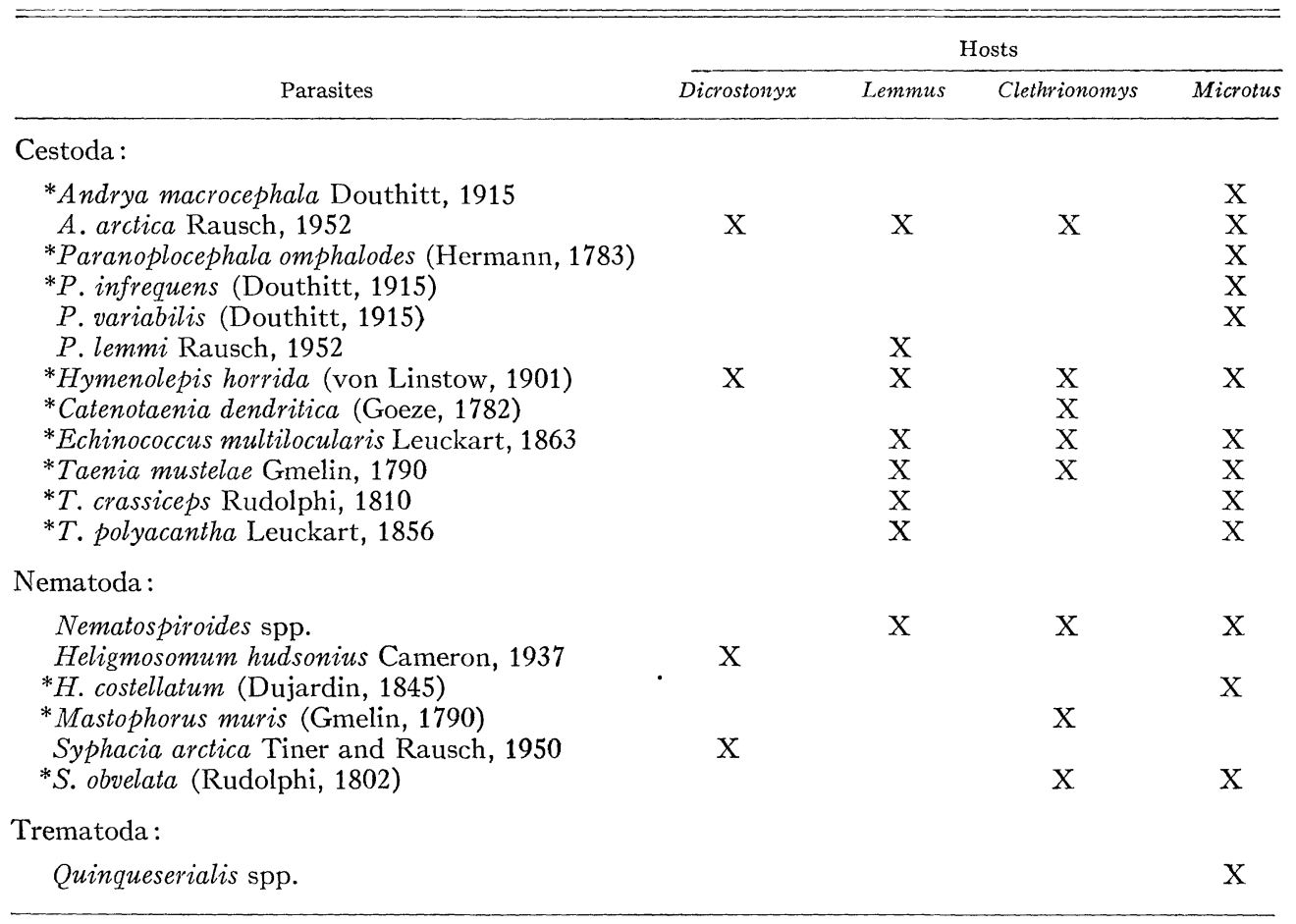

* Species known to be holarctic.

in Dicrostonyx in eastern Canada (Schad, 1954), and, of the larval cestodes, only those of Taenia crassiceps have been found in the collared lemming, and these in northern Canada (Rausch, 1952). In localities where Lemmus and Dicrostonyx occur together, a high proportion of the former may be found infected with the larval cestode, Taenia mustelae, the latter never. The definitive hosts of this cestode are Mustela erminea and $M$. rixosa, both frequently coexisting with the brown and collared lemmings. It would again seem that exposure to infection would be inescapable for Dicrostonyx. Further, larvae of Echinococcus multilocularis in experimentally-induced infections developed abnormally in Dicrostonyx as compared to Lemmus and Microtus (Rausch and Schiller, 1956). Two species of nematodes, however, are known only from Dicrostonyx; both, Syphacia arctica and Heligmosomum hudsonius, are found in the cecum, the latter coiled around the cecal villi.

The helminth fauna of Lemmus is much like that of Microtus. Only one cestode appears to be specific to Lemmus, Paranoplocephala lemmi, which is presently regarded as distinct from $P$. infrequens, although they are alike morphologically and ecologically; both are found in the cecum of the host. Lemmus can serve equally well with Clethrionomys and Microtus as an intermediate host for E. multilocularis.

Although the helminths of Synaptomys are poorly known, its affinities in this connection appear to be with Microtus. From the few specimens examined in Alaska, the writer has collected Paranoplocephala infrequens and the larval Taenia mustelae. $P$. variabilis has also been recorded from Synaptomys (Rausch, 1952), and in eastern Canada, Schad (1954) collected $P$. infrequens and $T$. tenuicollis $(=T$. mustelae $)$. 
Besides Dicrostonyx, the tribe Lemmini contains the genera Lemmus, Synaptomys, and Myopus (Simpson, 1945). According to Hinton (1926, p. 35), "Dicrostonyx is fundamentally the most primitive of the lemmings, and is by its structure one of the most isolated genera of the subfamily." The intestine of Dicrostonyx is modified to a degree not seen in the other genera considered here, in that the cecum possesses strongly developed villi (see Voge and Bern, 1955). In Lemmus and the nearctic Synaptomys, the cecum lacks villi and the intestinal tract more closely resembles that of Microtus. The writer has no information on the anatomy of the palearctic Myopus, whose helminths apparently have not been investigated.

In the writer's opinion, the host-parasite relationships discussed above clearly support Hinton's view that Dicrostonyx occupies an isolated position in the Microtinae. Excepting Myopus, for which little information is available, it might be said that Dicrostonyx differs more from the other genera of the tribe in important details of its structure and in its helminth fauna than the latter do from some members of the Microtini (e.g., Microtus).

The genera Clethrionomys and Microtus are included in the tribe Microtini. Clethrionomys is distributed over most of Alaska, where it is commonly found in the boreal forests, but it also occurs beyond the forest limits and may coexist at times with Dicrostonyx, Lemmus, and species of Microtus. In addition to those listed in Table 1, Andrya macrocephala has been reported from Clethrionomys in eastern Canada (Schad, 1954), and a questionable record of Paranoplocephala infrequens was given for Minnesota (Rausch and Tiner, 1949). The identity of the Syphacia in the red-backed vole has not been certainly defined, but excluding the possibility that it is hostspecific, the only helminth of red-backed voles not known in other microtine rodents is the cestode, Catenotaenia dendritica. The latter has been collected from animals taken in forested regions, so it is possible that its occurrence is more dependent upon the habitat of the host than upon host-specificity. The same possibility of an ecological specificity exists in the case of Mastophorus muris (Rausch, 1952; Schad, 1954). This nematode parasitizes Microtus in central North America.

The species of Microtus comprise a particularly homogeneous group, and the study of their helminths in North America has shown few differences in host-occurrence which cannot be explained as an effect of extrinsic factors (e.g., dissimilarities in the habitats of the hosts; restricted geographical distribution of certain species of helminths) (Rausch and Tiner, 1949; Rausch, 1952). But for $P$. lemmi, $P$. neofibrinus, and $A$. primordialis, all the species of anoplocephaline cestodes in North American microtine rodents have been reported from species of Microtus. Andrya bairdi, however, is known only from $M$. chrotorrhinus. Structurally, this vole is "... quite unique in the subgenus Microtus" (Bailey, 1900 , p. 58), and has a relatively limited range in eastern North America. Further investigation may prove that $A$. bairdi is specific for $M$. chrotorrhinus.

The occurrence of certain cestodes in Microtus spp. on islands in the Bering Sea suggests that they had differentiated before the end of the Pleistocene period, and prior to considerable evolutionary divergence in their hosts. Paranoplocephala omphalodes and $P$. infrequens, for example, are found in $M$. abbreviatus on St. Matthew Island. The St. Matthew group of islands is regarded as having been isolated since some time prior to the last Pleistocene glaciation, when the last landbridge between North America and Eurasia was present (Walters, 1955). Although some controversy exists as to whether $M$. abbreviatus is more closely related to $M$. oeconomus or to voles of the subgenus Stenocranius (represented by $M$. gregalis in Siberia, and by $M$. miurus in boreal North America), it is nevertheless specifically distinct. This 
suggests that the precursor of $M$. abbreviatus reached the St. Matthew Islands long before certain other species of microtine rodents invaded North America, probably via the last land-bridge (cf. Gilmore, 1942). Some of the latter, such as the holarctic Microtus oeconomus and $\mathrm{Cle}$ thrionomys rutilus, have diverged little in continental North America. That the cestodes $P$. omphalodes and $P$. infrequens could have been introduced to St. Matthew Island in more recent times is possible; infected mites conceivably might have been carried in by birds or in floating debris, but this seems most improbable.

The cestodes have not been investigated on the Pribilof Islands; since the latter are also in deeper water they would appear to have been isolated at least as long as the St. Matthew Islands. Here, the one species of microtine rodent present (Lemmus) is conspecific with that occurring on the North American continent. This fact, however, does not necessarily invalidate the hypothesis that the degree of divergence shown by $M$. $a b-$ breviatus is indicative of long isolation. On St. Lawrence Island, not isolated during the last Pleistocene glaciation, are found well differentiated subspecies of $M$. oeconomus and $C$. rutilus, both characterized by large size. Andrya macrocephala and $P$. infrequens have been collected here from $M$. oeconomus.

It appears, therefore, that anoplocephaline cestodes such as Paranoplocephala omphalodes, P. infrequens, and Andrya macrocephala existed in their present form prior to the invasion of North America by some of the species of microtine rodents now holarctic in their distribution. Relatively minor morphological changes have taken place in some of these rodents during and since the Pleistocene period, but there probably has been little or no change in their dietary habits, and none in their alimentary canals. Consequently, with little change in the habitats of the cestodes, it is probable that they have long been genetically stabilized.

Since some of these cestodes are now widely distributed over two continents, it is impossible to determine whether their origin was Eurasian or North American. However, it seems significant that the known North American range of $P$. omphalodes on the continent corresponds approximately to that of two holarctic species of voles, Microtus oeconomus and Clethrionomys rutilus, considered to be palearctic in origin (Gilmore, 1942 ; Zimmermann, 1942).

\section{Summary}

The taxonomic status of anoplocephaline cestodes of microtine rodents has been reviewed. Of the genus Andrya Railliet, 1883, five species are considered valid: A. macrocephala Douthitt, 1915; A. primordialis Douthitt, 1915; A. montana Kirshenblat, $1941 ; A$. arctica Rausch, 1952; A. bairdi Schad, 1954. Of the genus Paranoplocephala Luehe, 1910, six species are regarded as valid: $P$. omphalodes (Hermann, 1783); P. blanchardi (Moniez, 1891) ; P. infrequens (Douthitt, 1915) ; P. variabilis (Douthitt, 1915); P. lemmi Rausch, 1952 ; $P$. neofibrinus Rausch, 1952. Andrya caucasica Kirshenblat, 1938, and $A$. bialowizensis Sołtys, 1949, are regarded as synonyms of $A$. macrocephala. Paranoplocephala brevis Kirshenblat, 1938, is regarded as a synonym of $P$. infrequens. Three species, $A$. macrocephala, $P$. omphalodes, and $P$. infrequens, are holarctic in distribution, occurring mainly in species of Microtus.

The uniformity of microtine rodents as hosts for various helminths has been discussed. It is concluded that Dicrostonyx is the most isolated genus from this standpoint, having two nematodes which have not been recorded from members of other genera, and harboring few helminths in common with others. This agrees with Hinton's conclusions, based on morphological characters of Dicrostonyx.

From the present concept of Pleistocene glaciations, it is concluded that $P$. omphalodes and $P$. infrequens reached the St. Matthew Islands, in Bering Sea, as parasites of a vole from which Microtus ab- 
breviatus has evolved. It appears that this vole arrived on these islands before North America was invaded, in the late Pleistocene, by the palearctic $M$. oeconomus and Clethrionomys rutilus. The present known distribution of $P$. omphalodes in North America corresponds about to that of $M$. oeconomus on the continent.

\section{ACKNowledgments}

The writer acknowledges with thanks the assistance of Dr. J. Bernard, Station d'Entomologie de l'Etat, Gembloux, who kindly made available cestodes collected from voles in Belgium, and of Dr. $\mathrm{H}$. Vogel, Institut fuer Schiffs- und Tropenkrankheiten, Hamburg, with whom the writer collected helminths from small mammals in Germany.

\section{Literature Cited}

Baer, J. G. 1927. Monographie des cestodes de la famille des Anoplocephalidae. Bull. Biol. France et Belgique, supp1. 10. Soc. acad. U. Neuchâtel, Switzerland.

- 1932. Contributions à la faune helminthologique de Suisse. (Deuxième partie.) Rev. suisse Zool., 39: 1-57.

- 1949. Contributions à la faune helminthologique africaine. Acta Tropica, $6: 41-45$.

Bailey, V. 1900. Revision of American voles of the genus Microtus. N. Amer. Fauna No. 17, U. S. Dept. Agric., Washington, D. C.

Cameron, T. W. M., and I. W. Parnell. 1933. The internal parasites of land mammals in Scotland. Proc. Royal Physiol. Soc. Edinb., 22: 133-154.

Douthitt, H. 1915. Studies on the cestode family Anoplocephalidae. I11. Biol. Monogr., 1: $355-446$.

GILmORE, R. M. 1942. Review of Microtus voles of the subgenus Stenocranius (Mammalia: Rodentia: Muridae), with special discussion of the Bering Strait region. Doctoral diss., Cornell U., Ithaca, N. Y.

Hinton, M. A. C. 1926. Monograph of the voles and lemmings (Microtinae) living and extinct . Vol. I. Brit. Mus. (Nat. Hist.). London.

Joyeux, Ch., ANd J. G. Baer. 1936. Cestodes. Faune de France 30. Féd. Franç. Soc. Sc. Nat. Paris.

Kirshenblat, IA. D. 1938. Zakonomernosti dinamiki parazitofauny myshevidnykh gryzunov. Diss., U. Leningrad.

Pojmańska, T. 1956. Pasożyty wewnętrzne (Cestoda, Trematoda) drobnych ssaków polnych (Insectivora, Rodentia) $\mathrm{z}$ okolic turwi k. Poznania. Doniesienie tymczasowe. Wiadomości Parazyt., 2: 301-304.

Rausch, R. 1952. Studies on the helminth fauna of Alaska. XI. Helminth parasites of microtine rodents-taxonomic considerations. J. Parasit., 38: 415-444.

—- ANd E. L. Schiller. 1949a. A critical study of North American cestodes of the genus Andrya with special reference to $A$. macrocephala Douthitt, 1915. (Cestoda: Anoplocephalidae.) J. Parasit., 35: 306314.

—- AND - 1949b. Some observations on cestodes of the genus Paranoplocephala Luehe, parasitic in North American voles (Microtus spp.). Proc. Helminth. Soc. Wash., 16: 23-31.

— AND - 1956. Studies on the helminth fauna of Alaska. XXV. The ecology and public health significance of Echinococcus sibiricensis Rausch \& Schiller, 1954, on St. Lawrence Island. Parasit., 46: 395-419.

parasitic helminths of the North Central States. II. Helminths of voles (Microtus spp.). Preliminary report. Amer. Mid1. Nat., 41 : 665-694.

SchAD, G. A. 1954. Helminth parasites of mice in northeastern Quebec and the coast of Labrador. Canad. J. Zool., 32 : 215-224.

Simpson, G. G. 1945. The principles of classification and a classification of mammals. Bull. Amer. Mus. Nat. Hist., 85 : 1-350.

SoŁtys, A. 1949. Pasożyty wewnętrzne drobnych gryzoni leśnych (Muridae) Parku Narodowego w Białowieży. Ann. U. Mariae Curie-Sklodowska, 4 : 233-259.

Spasskit, A. A. 1951. Osnovy tsestodologii. Anoplotsefaliaty-lentochnye gel'minty domashnikh i dikikh zhivotnykh. Akad. Nauk SSSR. Moscow.

- , N. P. Romanova, and N. V. Naidenova. 1951. Novye dannye o faune paraziticheskikh chervei ondatry-Ondatra zibethica (L.). Akad. Nauk SSSR, Trudy Gel'm. 1ab., 5: 42-52.

Voge, M., And H. A. Bern. 1955. Cecal villi in Dicrostonyx torquatus (Rodentia: Microtinae). Anat. Rec., 123: 125-131.

Walters, V. 1955. Fishes of western arctic America and eastern arctic Siberia. Taxonomy and zoogeography. Bull. Amer. Mus. Nat. Hist. 106, Art. 5, pp. 225-368.

ŻARnowski, E. 1955. Robaki pasożytnicze drobnych ssaków leśnych (Rodentia i Insectivora) okolicy Pulaw (woj. lubelskie). I. Cestoda. Acta Parasit. Polonica, 3: 279368.

ZimmermanN, K. 1942. Zur Kenntnis von Microtus oeconomus (Pallas). Arch. Naturg., n. F., 11: 174-197. 